\title{
A NEW PRESSURE MEASURING SYSTEM FOR CUSHIONS AND BEDS-WITH A REVIEW OF THE LITERATURE
}

\author{
By L. K. Holley, J. Lon G, $†$ J. StewarT $\ddagger$ and R. F. Jones, F.R.C.S.(Ed.), \\ F.R.C.S., F.R.A.C.S., D.P.M., F.R.A.C.P.§ \\ * Queensland Institute of Technology, Brisbane, Australia; $\dagger$ Department of Rehabilitation \\ Medicine, Prince Henry Hospital, Sydney, Australia; $\ddagger$ Division Medical Physics, Prince \\ Henry Hospital; § Spinal Injury Unit, Department of Rehabilitation Medicine, Prince Henry \\ Hospital, University of New South Wales, Sydney, Australia
}

Abstract. An interface pressure measuring device for the assessment of subject-cushion interface pressures at ten points has been described. Preliminary trials using 12 healthy subjects on four cushions and three spinal injury patients on six cushions, has been carried out.

It was also found that the water and foam cushion distributed the pressure over a larger area than the foam cushions.

Key words: Pressure sores, pressure measurement, cushions.

\section{Introduction}

THE challenge of decubitus skin ulceration has exercised the minds of inventive people for hundreds of years (Jones, I97I). The cost in human suffering and on community resources is incalculable but no satisfactory device has been produced to prevent the development of pressure sores in the sedentary patient with lack of sensibility in the weight-bearing areas. The water or flotation bed has come a long way to preventing pressure necrosis in recumbent patients (Jones, I97I, 1975) but there are aspects of the flotation bed which may mitigate against its use.

A vast number of beds and cushions is currently on the market and the ability to objectively assess each of these devices against a standard or to compare the suitability of various cushions with each patient has been sadly lacking because the pressure measuring devices themselves have affected the weight relieving properties of the cushion or else they have had to be moved during the measuring analysis thus negating the results obtained.

New types of cushions are available as a result of research programmes in rehabilitation centres throughout the world and these include rubber and synthetic foam, gel types, water pads, impact absorbing varieties, flotation pads and various combinations.

The aim of our research into a pressure measuring system was to provide a direct pressure distribution measuring device and low cost with the capability of measuring normal forces over a large weight-bearing area without moving the subject or influencing properties of the cushion.

This paper sets out research and development of a relatively simple but effective pressure measuring device and reviews literature relating to decubitus skin ulceration and the measurement of the forces acting to cause the disturbance. 


\section{Review of the Literature}

Grant (1967) and Jones (I97I) give historical accounts of the research into pressure sores and the methods used in their alleviation.

The earliest description of decubitus skin ulceration and its treatment and prevention was by Neil Arnott in I833, 'Elements of Physics' (Arnott, I833).

That description was an accurate illustration of the factors involved in the causation of decubitus skin ulceration. Other authors, Norton (I962) and Lowthian (1970), have described two types of pressure sores. The first is superficial and is characterised by maceration of devitalised skin producing an infected shallow ulcer. The other is a deep ulcer which commences in the tissue overlying bony prominences. Here, considerable necrosis of muscle and fascia occurs, later extending to the surface. Erythema is the only evidence of skin involvement in the initial stages.

The cost in a hospital setting of preventive measures to reduce the incidence of pressure necrosis may reduce the costs of hospitalisation of patients with paralysis by a factor of 50 per cent (Cox, I976).

Trumble (1930) postulated two important factors in the development of pressure necrosis, the intensity and the duration of the pressure effect. Experimentally, Trumble found that on a boy's foot, a pressure of 2.5 p.s.i. ( $17 \cdot 2 \mathrm{kPa}$ ) was required to obliterate a systolic blood pressure of $120 \mathrm{mmHg}(15.9 \mathrm{kPa})$ whereas a pressure of $\mathrm{I} \cdot 6$ p.s.i. ( $\mathrm{I} \cdot \mathrm{\circ} \mathrm{kPa}$ ) could be tolerated for days. He also calculated that in the recumbent position the average pressure experienced by the body may not exceed 0.33 p.s.i. $(2 \cdot 2 \mathrm{kPa})$, but due to body irregularities the pressure over areas such as bony prominences is much higher. Reichel (1958) first postulated that shearing forces are important in the genesis of a pressure sore. He postulated that shearing forces placed the blood vessels under stretch and/or angulation. Ultimately extensive tissue dissection or cleavage could occur which might be the precipitating factor in causing a pressure sore to develop. Lowthian (I970) used a rubber block to simulate tissue. He drew horizontal and vertical lines on the block. Compressive and shear forces were used to load the block, similar to the manner in which tissue is loaded. From the final distortion taken up by the lines, he postulated that shear compressive forces occlude blood vessels contributing to the formation of the deep pressure sore. Spence (1967), Cochran (I973) and Dawson (1974) indicated that shearing forces should be eliminated if adequate control over the development of pressure sores were to be maintained. No experimental evidence was produced to show the role that shear plays in the initiation of a pressure sore. Stark (1977) showed that with shear forces, collagen fibres begin to align, gradually causing occlusion of blood vessels in the fibre matrix.

Other authors, Guttman (I955), Norton (I962), Jones (I97I) and Cox (I976), include physical damage to tissues, ischaemia, anaemia, age, nutritional inadequacy, loss of vasomotor control, lack of skin sensation, local infection, presence of endotoxins, use of corticoids, muscle wasting, diabetes and oedema as factors which are likely to cause pressure sores to develop. It is generally held that the most important factors causing pressure sores are prolonged and/or excessive pressure, shear forces, friction and moisture.

Experimental studies have been undertaken by many workers; Brooks and Duncan (1940) used rats as their experimental animal. Pressures were applied to the tail for varying lengths of time, and the external evidence of necrosis was noted. They also studied the circulation of the tail under these conditions using 
radio-opaque dye and X-rays. Their conclusion was that pressure causes circulatory obstruction and pathological changes. Necrosis of tissue did not occur in less than 17 hours or at pressures less than $70 \mathrm{mmHg}$. Reduced temperatures reduced the occurrence of necrosis. Kosiak (1959) established a pressure-time relationship for the onset of necrosis using a dog's legs as the area for experimentation. This inverse relationship has gained acceptance as being valid for the onset of necrosis in humans. In that experiment, friction was not considered. Kosiak did determine, however, the amount of pressure transmitted through the tissues and found that 58 per cent of the surface pressure was transmitted to the subcutaneous tissue. At I-cm depth 38 per cent was transmitted and 33 per cent was transmitted to subcutaneous tissue on the other side of the leg.

In I96I Kosiak investigated the effect of constant and alternating pressure on normal and denervated muscle. Using rats, he investigated the microscopic changes in the muscle tissue and found that there was no significant difference between normal and denervated tissue. Dinsdale (1973) confirmed these findings. A constant pressure of $70 \mathrm{mmHg}$ produced a change in the tissue after 2 hours and with alternating pressure, minimal change was noted up to $240 \mathrm{mmHg}$ and that ulceration generally occurred 3 to 4 days after removal of the pressure. Lindan (I96I) applied pressure to rabbits' ears and observed the vascular response. Pressure above $100 \mathrm{mmHg}$ removed the blood from the area, and necrosis occurred if the pressure was maintained for more than 12 hours. These experiments confirmed the conclusions of Kosiak.

Dinsdale (1973-74) contributed to the understanding of the pathogenenis of decubitus ulcers by undertaking experiments on paraplegic swine and normal swine, investigating the muscle tissue at the point of applied pressure using light and electron microscopes.

The sequence of events observed was:

I. Desquamation of the stratum corneum.

2. Hyperaemia in the capillaries and venules of the superficial dermis.

3. Increased pressure leading to haemorrhage, leukocyte infiltration near the capillaries and venules of the superficial dermis.

4. Necrosis of the superficial dermis and detachment from the basal cells.

5. Thrombosis in venules and capillaries of superficial dermis.

6. Decrease in the capillary lumina due to (7).

7. Endothelial cell swellings. (The area of the lumen in the normal capillary is 45 per cent of the total cross-section.)

Dinsdale's second set of experiments was performed to determine the relationship of friction and pressure in causing necrosis. Normal pressure was applied by exerting a force on a $2.45 \times 2.45 \mathrm{~cm}$ square metal plate. The method of applying friction was not disclosed. With only pressure, $290 \mathrm{mmHg}$ was required to produce necrosis, while with both pressure and friction, the minimal normal pressure which produced necrosis was $45 \mathrm{mmHg}$. In this experiment, the pressure was applied in three $\mathrm{I} \cdot 5$ hour periods with $\mathrm{I} 5 \mathrm{~min}$ break for I week. Using perfusion techniques it was found that friction did not cut off the blood supply or cause ischaemia but an experimental ulcer which correlated with a clinical ulcer required both friction and ischaemia. From the studies of the pathogenesis of a pressure sore and the anatomy of the skin it may be concluded that friction removes the outer protective stratum corneum, and thus accelerates onset of a pressure sore. These experiments support the importance of a pressure-time relationship for the onset of a decubitus ulcer. 


\section{Support Systems (Pressure Relieving Beds and Cushions)}

Once the principle of pressure as the aetiological factor of pressure necrosis over bony prominences was established, many beds, cushions and other devices were invented and constructed to relieve the high-pressure concentration about these points.

The first water bed was designed in 1833 , technical problems did not allow its full use till recently (Jones, I97I). Weinstein (1965) added lead carbonate and high viscosity oil to prevent the patient from sinking into a flotation cushion but maintaining the hydrostatic support. A similar design was presented by Reswick (I972) using barytes and Bentonic clay. Other beds developed to relieve pressures including alternating moving slats (Molnar, 1972), Air Fluidised Bed system (Hargest, I976), low pressure beds (McCubbin, I972),

Equally as prolific is the number of wheelchair cushions designed to prevent sores. Mooney (I97I) and Cochran (1973) have attempted to outline the essential requirements for a useful cushion. The cushion must keep direct pressures and shear forces low but at the same time provide stability and comfort. It should be light, of a manageable size, inexpensive and have a life expectancy of 6 months or more. The choice of covering should also be carefully made. It has been shown (Chow, 1976) that the covering does change the properties of the cushion regarding shear. Ideally the cover should be absorbent, permit air circulation and be easily replaceable and washable by the person using the cushion.

The types of cushions now available can be classified into six groups.

I. Foam type (Koreska, I975; Ma, 1976).

2. Gel type (Paradise, 1975; Spence, 1976).

3. Water type (Weinstein, I966).

4. Negative pressure type (Oates, 1975).

5. Air type.

6. Sheepskin and artificial fibre pads.

Other pressure-relieving devices include, cut-out boards (Ma, I976), a 'rocking chair' wheelchair (Jackson, 1975), a wheelchair with a cushion of moving rollers (Kosiak, I976), moulded plaster bucket seats (Hassard, I97I) and a warning device which encourages the person to lift in the chair every 2 hours (Malament, I975). No cushion developed so far appears to be capable of maintaining pressures lower than capillary pressures or even less than $50 \mathrm{mmHg}$ beneath sitting patients (Houle, I969; Mooney, I97I ; Souther, I974; De Lateur, 1976). It can be shown that a 70-kg person sitting on an area of $900 \mathrm{~cm}^{2}$ exerts an average pressure over his buttocks of $57 \mathrm{mmHg}$. The pressure will be much greater over the bony prominences. A cushion which enables a greater area of the person to be used in the supporting role and provides even support over this area is required.

\section{Measuring Techniques}

The measurement of pressure and shear at the interface of skin and a supporting structure is theoretically an insoluble problem since the introduction of any measurement device alters the system. Results are inevitably influenced by the measurement techniques employed.

Landis (I962) used the micro-injection technique to determine the pressure in the capillaries of human skin. The average pressure in the arteriolar end of the capillary network was found to be $32 \mathrm{mmHg}(4 \cdot 27 \mathrm{kPa})$. This figure has been 
quoted as the optimum value to be reached for the cushion-skin interface. Kosiak (I958) employed rubber butterfly valves as the sensor under the patient, the pressure necessary to force air through these valves being considered to be the interface pressure. Lindan (1965) produced the 'Bed of Nails and Springs'. Nails and springs were placed at I $\mathrm{cm}$ intervals over a hard board. When a person lay on the 'bed' the springs were compressed. Readings of the amounts of compression were taken for all nail-spring pairs and converted to pressure. This was the first attempt to determine an over-all pressure distribution of the body. For routine use, this method has its limitations as the time taken for one set of results may be up to $\mathrm{I} \frac{1}{2}$ hours, and the compliance of the device bears no relation to that of a cushion.

Another attempt to obtain an overall distribution was by Frisina (I970). He developed a chemical method which used the principle of a pressure-controlled chemical reaction. Chemicals were deposited on a sheet of paper which was placed under a person, the differing pressures controlling the rate of reaction between a mild acid and acid indicator resulting in a coloured contour pressure map. The colour change was proportional to reaction rate which was in turn proportional to pressure. Temperature effects negated the method as a useful system. Bauman and Brand (1963) and Bush (1969) developed and extended a capacitor pressure transducer. This transducer relied on the pressure to change the capacitance. Leremis (1973) used the principle of strain gauges on a cantilever to measure the normal pressure under the feet. The gauges were connected to a wheatstone bridge, and with five strain gauge-cantilever devices five pressures were monitored simultaneously. This was expensive and clumsy for use in a clinical environment. Recently, the Kulite Company developed a miniature pressure transducer consisting of a wheatstone bridge directly mounted on to a silicon diaphram. It was shown to be useful in the measurement of stump pressures in artificial limbs (Rae, I97I). The company also developed a 25-channel pressure sensing module, which had provision for direct entry into a computer, increasing data productivity and on-line calibration using a reference pressure on all channels. This system was very expensive. A simple, easy-to-use pressure device was developed at the Rancho Los Amigos Rehabilitation Centre, described by Mooney (I97I) as a copper grid on either side of a flexible P.V.C. air-tight pneumatic cell (Fig. I). When an external pressure was being exerted on the sensor, the internal pressure which caused the sensor to just make or break contact was indicated by a light going out. When an external pressure is being exerted on the sensor the internal pressure which causes the sensor to just make or break contact is said to be equivalent to that external pressure. This device has been widely used (Jeneid, I974; Keswick, private communication). However, it has the following shortcomings.

I. There is only one sensing area.

2. The sensing area is quite large $\left(7 \mathrm{~cm}^{2}\right)$.

3. The P.V.C. sensor is not very strong which leads to air leakage and unreliable results.

\section{Interface Pressure Measurement System-Design and Construction}

The basic design consists of a water-filled, water-tight, air-tight cell connected to a physiological pressure transducer via a length of vinyl tubing. When a force is exerted on the cell the pressure developed is transmitted to the transducer. 


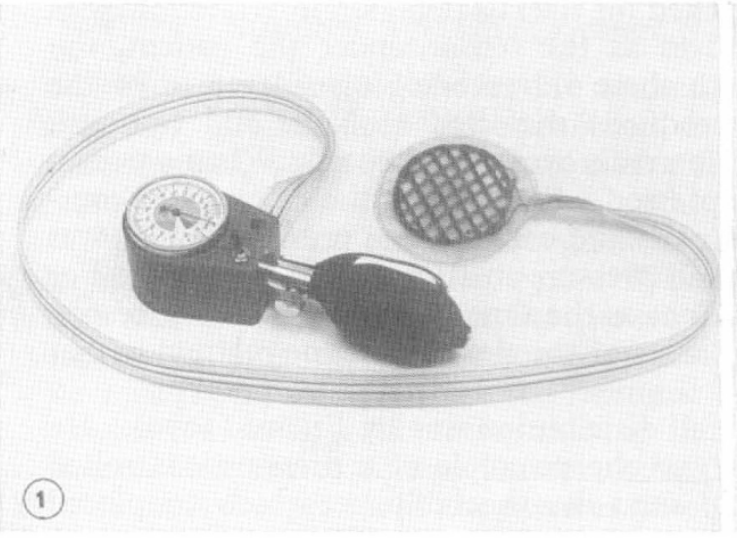

FIG. I

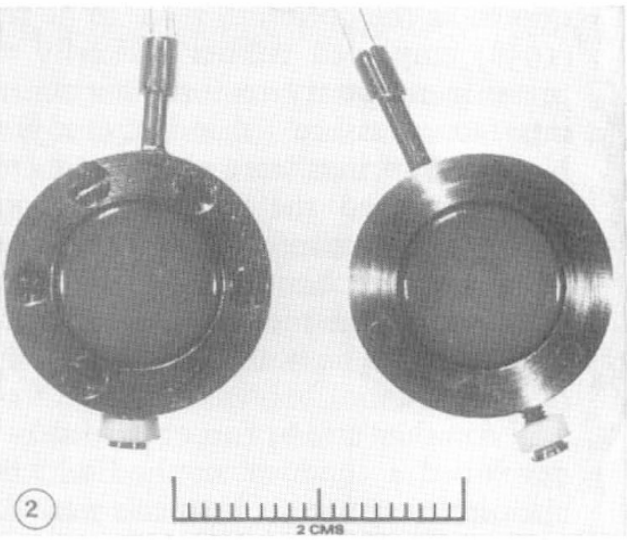

FIG. 2

The volume displacement is converted to an electrical signal which can be displayed on a meter.

The pressure cell consists of a membrane clamped over a metal ring, I cm internal diameter, $\mathrm{I} \cdot 7 \mathrm{~cm}$ outside diameter and $0.5 \mathrm{~cm}$ thick (Fig. 2). The membrane is constructed from vinyl and clamped in place as shown (Fig. 2). Vinyl was chosen as the membrane material because it is easily manipulated and relatively durable. However, because of its elastic nature the volume of water must be kept constant to ensure consistent zeroing at the output. A system using ten pressure cells was chosen, this number being a compromise between the requirement to measure at many points and convenience of use. A simple switching network was required to avoid costly multiple transducer connections. A ten-way valve (Fig. 3) was designed and constructed. It contains ten inputs and one output. A cock rotates and connects each input to the output individually. The compact valve does not allow two or more cells to be connected to the pressure transducer simultaneously. The pressure recorded by the transducer is due to a volume displacement. When the cock rotates the cock-transducer line retains the pressure and hence an additional volume of water from the previous cell causing an error in the zero for the next cell. To avoid this zero error, the centre of the ten-way valve has a connection to the zero pressure reference. This allows the cocktransducer line to be automatically zeroed as the cock moves from one cell to the next.

The transducer used to detect the pressures is a Bell and Howell physiological pressure transducer (Model 4-327-I). The transducer contains a flexible molybdenum stainless steel membrane with a rod mounted on the internal surface. The rod is connected to strain gauges which are arranged in a wheatstone bridge. The transducer is connected to a Cardiotrace 2000, which is an amplifying recording instrument. The output cable of the Cardiotrace contains two excitation leads, two transducer output leads and a shield which is earthed at the preamplifier. The excitation leads carry a balanced $5 \mathrm{~V} \mathrm{rms,} 2.4 \mathrm{kHz}$ signal to the wheatstone bridge. Change in the external pressure will distort the transducer membrane which in turn causes an imbalance in the wheatstone bridge. The resultant signal across the transducer output ( $350 \mathrm{ohm}$ impedance) is proportional to the pressure being monitored. This signal is amplified and displayed. The DC output from the Cardiotrace was connected to a digital voltmeter to obtain 


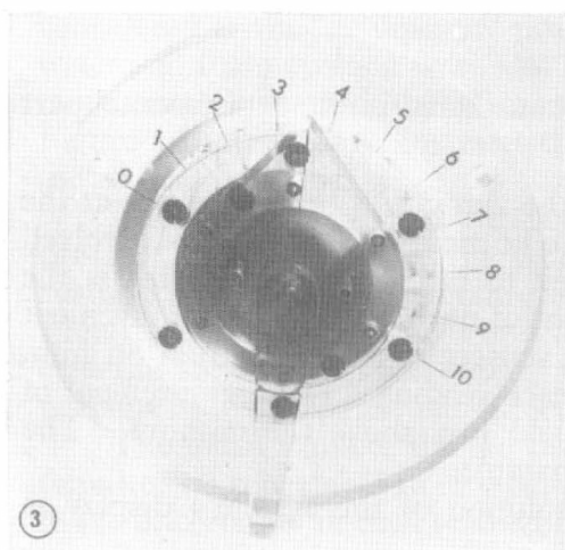

FIG. 3

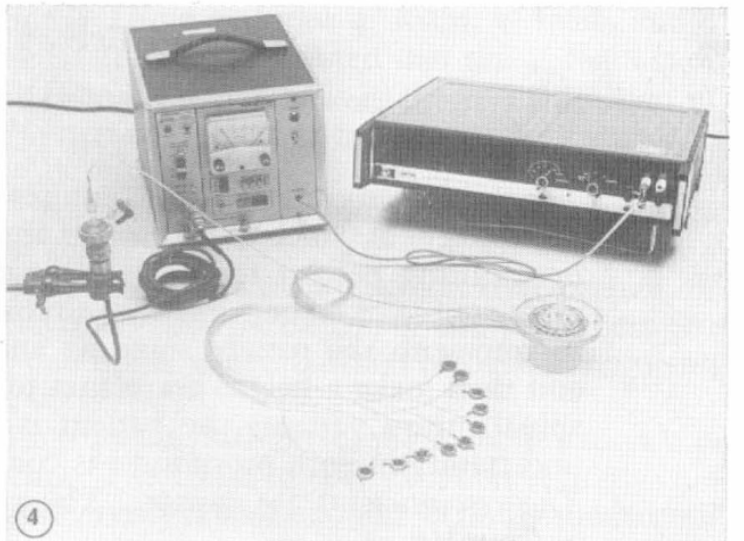

FIG. 4

greater resolution. The preamplifier is capable of handling transducers with sensitivities ranging from $5 \mu \mathrm{V} / \mathrm{mmHg}$ to $12.5 \mathrm{mV} / \mathrm{mmHg}$. The Bell and Howell transducer has a sensitivity of $5 \mu \mathrm{V} / \mathrm{VcmHg}$ ( \pm I per cent). The final system (Fig. 4) consists of ten pressure cells linked to a physiological pressure transducer via water-filled vinyl tubes and a ten-way valve. The output from the pressure transducer is detected, amplified and displayed by a Cardiotrace 2000 .

\section{Testing Procedures}

Measurements of the subject-cushion interface pressure were undertaken to study the distribution of pressure for different cushions. To carry out this study, a regime was established to standardise the measurements. The regime is as follows:

I. The cells were placed in a matrix which was then taped on to the subjects, with two cells as near as possible to the ischial tuberosities.

2. The cells were zeroed with subject standing (healthy) or raised just above the cushion (spinal injury patients) using the reference pressure which is a container of water set at a predetermined height prior to use. Each cell is opened to this reference, the volume of water in the cells is returned to the original amount and the unloaded cells record a zero pressure. The system is ready to take the next set of values. In practice, the time taken to re-zero is approximately I0-20 sec.

3. The subject was seated on the chair with both feet flat on the floor or wheelchair support, hands resting in front and back supported by the back of the chair.

4. The pressures were recorded on each cell.

5. The cells were zeroed while the cushion was changed, with the subject in the same position as in 2 .

6. Readings were repeated for the different cushions.

7. The height of the cells at the zeroing position, with respect to the final position during measurement, was recorded. Each reading was adjusted by the appropriate height factor. 


\section{Errors}

In this system, the errors which are to be considered in the experimental part are:

I. The zeroing procedure. This requires the zeroing to be carried out at the same height at which the pressures are to be measured. The error involved here during patient testing is estimated to be $\pm 3 \mathrm{mmHg}$. This is the main source of error. For measurement of normals it is more convenient to zero with the patient standing and sensors taped in position on him, and then make a height correction to each reading. For measurement of spinal injury patients the patient is held just above the cushion. The uncertainty in both procedures is comparable.

2. The resolution of the system. The resolution of the system's display is $\pm \mathrm{I} \mathrm{mmHg}$.

3. The perturbing effects of the cells at the interface. In absolute terms this is unknown, but for purposes of comparative studies it is assumed constant for all subject-cushion interface and has not been included.

The total estimated error in each reading is approximately $+5 \mathrm{mmHg}$. This represents an error of less than io per cent for the values expected to be measured.

\section{Results and Discussions}

Preliminary studies were done to test the reliability and repeatability of the sensor system.

Two studies were undertaken, one with healthy subjects, and the other with spinal injury patients.

I. Twelve normals of varying weight and age and both sexes were used in this study. A chair with standard heavy vinyl-covered 2 " foam was used and

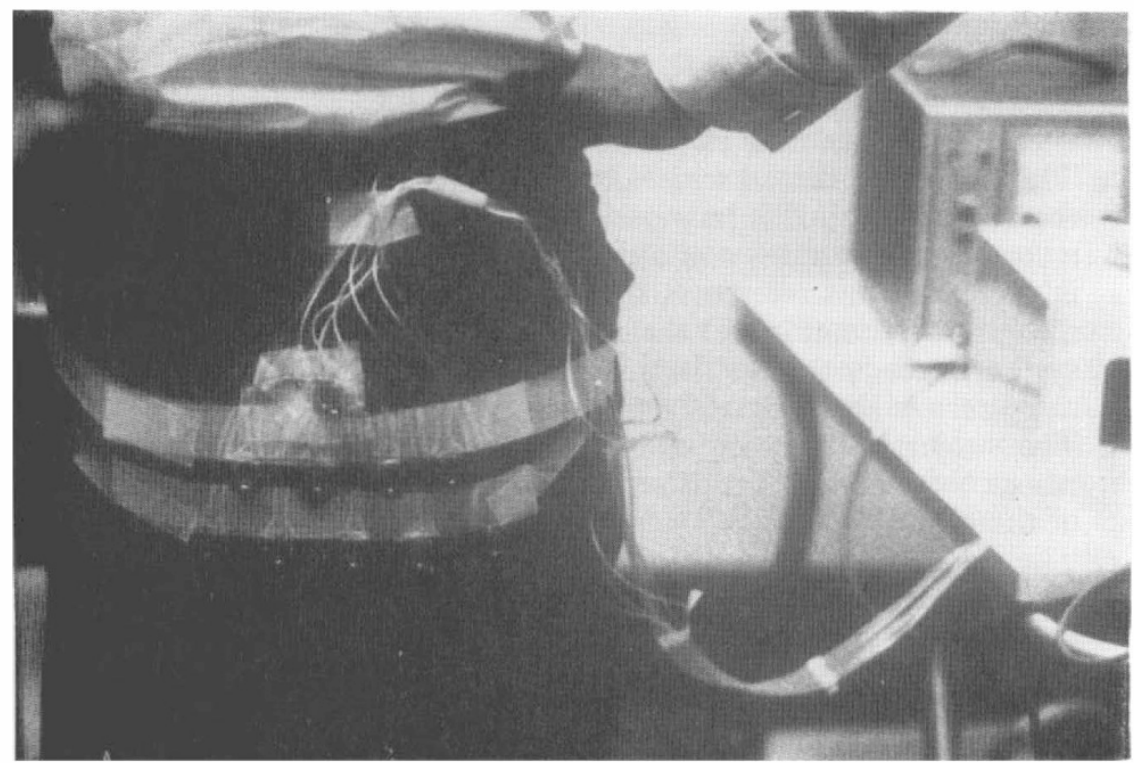

FIG. 5 
considered as the 'no cushion' position. Three cushions 4 " foam, 3 " foam, and a water and foam cushion were also used. It should be noted that the $3^{\prime \prime}$ foam is of more dense type than the $4^{\prime \prime}$ foam. The matrix of cells is shown in position in Figure 5 and Figure 6 illustrates the system in use. The matrix was kept standard for all healthy subjects.

The sum or mean of the ten pressures gives an indication of the average pressure distributed over the whole area. This value will indicate how well a cushion distributes the pressure over the whole buttock-cushion contact area, of which the measured region is only a fraction. The means can be compared between cushions for an individual subject to determine which cushion is 'best' at reducing pressures for that particular subject.

The mean value of the ten readings for any subject-cushion combination was found to be repeatable to \pm 5 per cent. The cause of this variation is firstly due to the uncertainty in each reading as previously discussed, and secondly the natural variation in sitting positions when a subject re-seats himself. This causes an unavoidable redistribution of pressure between the back of the chair, the buttocks, the thighs and the feet.

The standard deviation of the ten values was used as a measure of the 'peakiness' or unevenness of the distribution of pressure over the area covered by the matrix. The smaller the standard deviation, the better is the cushion in eliminating very high and low pressure points.

Table I contains the means and standard deviations of the ten pressures for each subject-cushion combination for healthy subjects. From these values it can be clearly seen that the 'no cushion' position gives both the highest mean and standard deviation in all cases except one. This implies a poor weight distribution over the whole buttock-thigh region and large variations in the pressures over the ischial tuberosity-sacral region.

To determine whether there was a significant difference between the water

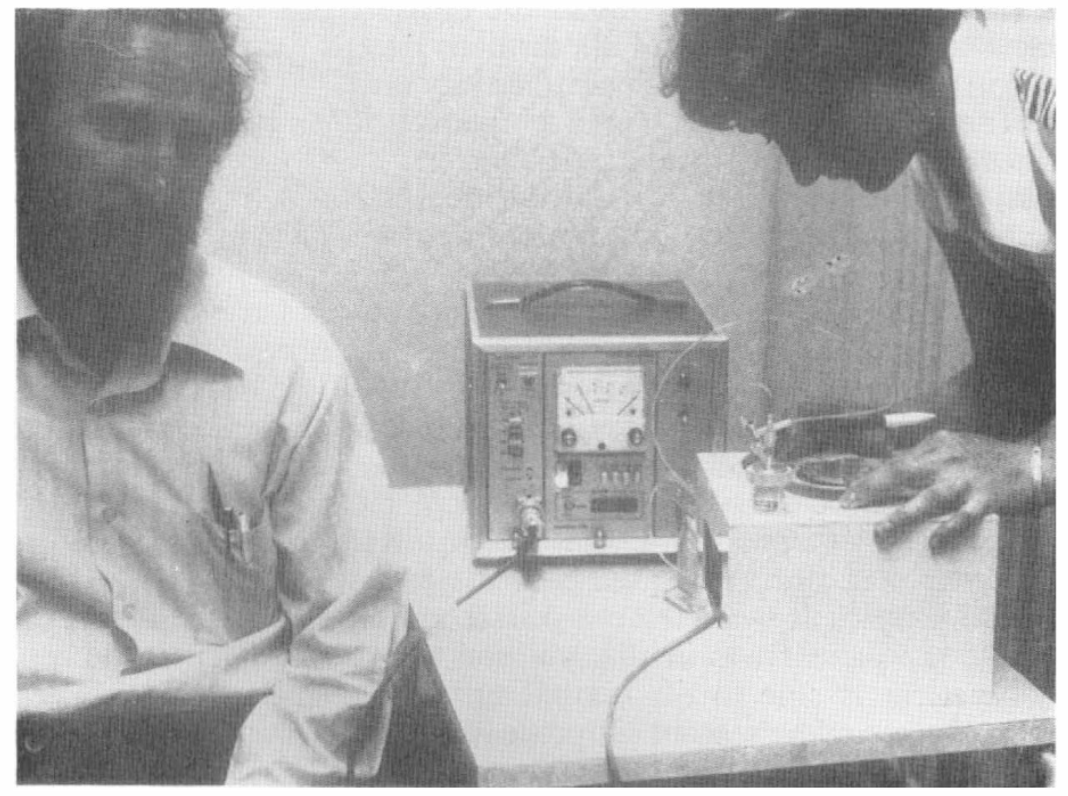

FIG. 6 


\section{TABLE I}

Means and standard deviations ${ }^{\star}$ for ten interface pressures for healthy subjects on four cushions

\begin{tabular}{|c|c|c|c|c|c|c|c|c|c|}
\hline \multirow[t]{3}{*}{ Subjects } & \multirow{3}{*}{$\begin{array}{l}\text { Weight } \\
\text { (kg) }\end{array}$} & \multicolumn{8}{|c|}{ Cushions } \\
\hline & & \multicolumn{2}{|c|}{ No cushion $†$} & \multicolumn{2}{|c|}{$4^{\prime \prime}$ foam } & \multicolumn{2}{|c|}{$3^{\prime \prime}$ foam } & \multicolumn{2}{|c|}{ Water \& foam } \\
\hline & & Mear & S.D. & Mear & S.D. & Mea & S.D. & Mea & S.D. \\
\hline I & 102 & I I 4.4 & $3 \mathrm{I} \cdot 2$ & $96 \cdot 8$ & I $7 \cdot \mathrm{I}$ & $58 \cdot 6$ & I $8 \cdot 3$ & $77 \cdot 5$ & $20 \cdot 3$ \\
\hline 2 & 67 & 68.9 & $12 \cdot 4$ & $70 \cdot 2$ & 13.4 & 74.9 & 15.0 & $52 \cdot 5$ & 13.0 \\
\hline 3 & $8 \mathrm{I}$ & $97 \cdot 8$ & $38 \cdot 2$ & $8 \mathrm{I} \cdot 7$ & $27 \cdot 7$ & 83.4 & $23 \cdot 6$ & $74 \cdot 0$ & $25 \cdot 7$ \\
\hline 4 & 72 & $83 \cdot 6$ & $20 \cdot 2$ & $67 \cdot 4$ & $8 \cdot 6$ & 55.9 & $9 \cdot 9$ & $62 \cdot 0$ & I 4.8 \\
\hline 5 & 64 & $97 \cdot I$ & $44 \cdot 6$ & $64 \cdot I$ & $14 \cdot 2$ & $59 \cdot 4$ & $29 \cdot 6$ & $59 \cdot 5$ & I6.8 \\
\hline 6 & 67 & - & - & $57 \cdot 3$ & $22 \cdot 6$ & 59.8 & 15.5 & $66 \cdot 7$ & I $8 \cdot 2$ \\
\hline 7 & 65 & $92 \cdot I$ & $24 \cdot 7$ & $60 \cdot 7$ & $23 \cdot I$ & $66 \cdot 2$ & $24 \cdot 4$ & $67 \cdot 7$ & $27 \cdot 7$ \\
\hline 8 & 75 & I I $6 \cdot I$ & $20 \cdot 2$ & $84^{\cdot I}$ & $12 \cdot 9$ & $84 \cdot I$ & $15 \cdot 2$ & $78 \cdot 9$ & I $7 \cdot \mathrm{I}$ \\
\hline 9 & 89 & II 5.6 & $36 \cdot 5$ & $97 \cdot 3$ & I7.8 & 93.9 & 15.0 & $78 \cdot 6$ & I3.4 \\
\hline IO & 59 & $90 \cdot 6$ & $22 \cdot I$ & $67 \cdot 2$ & 13.9 & $62 \cdot 8$ & I3. 8 & $7 \mathrm{I} \cdot 3$ & $20 \cdot 2$ \\
\hline I I & 55 & $85 \cdot 4$ & I6.8 & $65 \cdot 0$ & $10 \cdot 8$ & 65.9 & I6.6 & 63.0 & I $8 \cdot 7$ \\
\hline I 2 & 62 & $97 \cdot 6$ & $34 \cdot 3$ & $80 \cdot 6$ & I $5 \cdot I$ & $68 \cdot 4$ & $24 \cdot 6$ & $65 \cdot 8$ & $16 \cdot 3$ \\
\hline
\end{tabular}

S.D. = Standard deviation.

$\star$ Units of mmHg.

† Standard 2" vinyl convered foam seat.

and foam cushion and the 4 " foam cushion, a $t$-test was performed. It was found that at the Io per cent level, the water and foam cushion gave significantly lower mean values, but the standard deviations were not significantly different. Hence, the water and foam cushion distributes the pressure more evenly over the whole buttock-cushion contact area, and all cushions except the 'no cushion' are equal in spreading the load over the ischial tuberosity area.

No difference between the $3^{\prime \prime}$ and 4 " foam cushions could be discerned either for the mean value or for the standard deviation.

Thus, in this study the water and foam cushion was found to be superior in reducing high pressure points and distributing the weight evenly over the sitting area.

A brief study to examine the effect different covers have on the pressure distribution was carried out. The covers examined included vinyl, rubber mackintosh, terry towelling, cotton and material on vinyl. The covers were placed separately on the 4 " foam cushion and the pressure distribution determined. No significant difference was found between the means or standard deviations for all the covers, but a more extensive study needs to be carried out.

Subsequently, one paraplegic and two quadriplegic patients were examined. This study was performed using the patient's own wheelchair. The patient was held over the wheelchair while the cell matrix was taped over the ischial tuberosity area. While the patient was in this position the pressure cells were zeroed. A paraplegic patient is able to lift himself up to a height where zeroing may be achieved. The complete measuring procedure for one cushion requires between 3-4 min. Six cushions were used in this study.

It should be noted that the two quadriplegic patients slumped markedly into 
the wheelchair, with a high percentage of their weight being supported by the spine and the superior gluteal area. In this position the ischial tuberosities were supporting much less weight than in an upright patient. Also, it was more difficult to place the patient in the same position on each cushion.

Because the patients were unable to place themselves back into a reproducible position, the readings show a large scatter. The results (means and standard deviations) are tabulated in Table II. In those cases where a repeat measurement was taken the results appear to be reasonably consistent, but it is felt that no conclusive statement regarding the 'best cushion' for a spinal injury patient can be made. More clinical work needs to be carried out with improved methods for repositioning the patients, with the cells taped directly on the skin, and with more attention being paid to patient movement during the procedure as well as considering parameters not related to pressures but important in choosing a suitable cushion.

\section{Summary AND CONCLUSION}

An interface pressure measuring device for the assessment of subject-cushion interface pressures at ten points has been described. Preliminary trials using I2 healthy subjects on four cushions and three spinal injury patients on six cushions, has been carried out. Any measuring device will perturb the interface to an unknown extent. Despite this, the system described has proved useful for quick repeatable, comparative measurements of different cushions.

The results from the healthy subjects indicate that there is a significant difference between the average pressure with a cushion and the average pressure without a cushion. It was also found that the water and foam cushion distributed the pressure over a larger area than the foam cushions.

The results from the spinal injury patients are too brief to make a statement on the relative merits of the cushions used.

Some authors (Mooney, I97I) have indicated that the water cushions have similar pressure distributing properties as the foam cushions, whereas other authors (Souther, 1974) have shown that the water cushions reduce the pressures to a greater degree than the foam cushions. A third statement by Cochran (I973) regarding the comparative merits of these two cushions contradicts the first two.

\section{TABLE II}

Means and standard deviations ${ }^{\star}$ for ten interface pressures for spinal injury patients on six cushions

\begin{tabular}{|c|c|c|c|c|c|c|c|c|c|c|c|c|c|}
\hline \multirow[t]{3}{*}{ Subjects } & \multirow{3}{*}{$\underset{(\mathrm{kg})}{\text { Weight }}$} & \multicolumn{12}{|c|}{ Cushions } \\
\hline & & \multicolumn{2}{|c|}{ Bye Bye } & \multicolumn{2}{|c|}{$3^{\prime \prime}$ Foam } & \multicolumn{2}{|c|}{ 4" Foam } & \multicolumn{2}{|c|}{ Water \& Foam } & \multicolumn{2}{|c|}{ Tripad } & \multicolumn{2}{|c|}{ Dunlopillo } \\
\hline & & Mea & S.D. & Mear & S.D. & Mea & S.D. & Mear & S.D. & Mea & S.D. & Mea & S.D. \\
\hline I & 52 & $\begin{array}{l}23.3 \\
28 \cdot 2\end{array}$ & $\begin{array}{r}7.6 \\
16.7\end{array}$ & $23 \cdot 2$ & II 9 & $27 \cdot 0$ & 13.7 & $\begin{array}{l}34 \cdot 2 \\
3 \mathrm{I} \cdot \mathrm{I}\end{array}$ & $\begin{array}{l}29 \cdot 3 \\
17 \cdot 6\end{array}$ & $\begin{array}{l}44 \cdot 7 \\
42 \cdot 6\end{array}$ & $\begin{array}{l}\mathrm{Ir} \cdot 4 \\
13 \cdot 2\end{array}$ & $\overline{-}$ & $=$ \\
\hline 2 & 67 & $\begin{array}{l}49 \cdot 0 \\
84 \cdot 2 \\
-\end{array}$ & $\begin{array}{l}4 \mathrm{I} \cdot 4 \\
5 \mathrm{I} \cdot 4 \\
\end{array}$ & $\begin{array}{c}23 \cdot 8 \\
26 \cdot 1 \\
-\end{array}$ & $\begin{array}{l}15.0 \\
15.8 \\
-\end{array}$ & $\begin{array}{l}28 \cdot 3 \\
二\end{array}$ & $\begin{array}{l}31 \cdot 2 \\
-\end{array}$ & $\begin{array}{l}36 \cdot 7 \\
50 \cdot 0 \\
38 \cdot 1\end{array}$ & $\begin{array}{l}14 \cdot 6 \\
13 \cdot 2 \\
\text { II. I }\end{array}$ & $\stackrel{4 \mathrm{I} \cdot 0}{=}$ & $\begin{array}{c}21 \cdot 9 \\
-\end{array}$ & $\stackrel{40.5}{=}$ & $\begin{array}{l}14.5 \\
-\end{array}$ \\
\hline 3 & 71 & $6 \mathrm{I} \cdot 6$ & $26 \cdot 4$ & $45 \cdot 2$ & $19 \cdot 2$ & $\underline{49 \cdot I}$ & I6.3 & $\begin{array}{l}60 \cdot 6 \\
62 \cdot 2\end{array}$ & $\begin{array}{l}16.3 \\
18.4\end{array}$ & $59 \cdot 1$ & I4.4 & $62 \cdot 7$ & $2 \mathrm{I} \cdot 8$ \\
\hline
\end{tabular}


Cochran states that the clinical results have not been outstanding for water cushions whereas for foam they are promising. This disparity between other authors highlights the difficulty in assessing cushions regarding their pressure-distributing qualities.

With future studies some modification is needed regarding the procedure. The cells should ideally be placed directly on to the skin to improve repeatability. Each cushion should be preloaded for some time before measurements are taken. This will simulate more closely the effect the cushion has on the pressure distribution after the cushion has settled.

\section{RÉSUMÉ}

De nombreux facteurs contribuent à la formation des Decubitus, la pression excessive et prolongée étant le facteur dominant.

Le problème est le plus sévère pour le malade assis, parce que le même poids se distribue sur une surface bien plus petite que lorsque le malade est couché.

Un appareil nouveau est demontre. L'appareil est composé de dix sensorimètres reliés via un transducteur de pression physiologique à un système d'amplification et d'enregistrement. Ce qui suit est une description de l'appareil illustrée par quelques résultats typiques.

L'appareil se base sur un transducteur de pression physiologique de type courant. Dix sensorimètres remplis d'eau sont relies au transducteur par un tuyau plastique qui passe par un commutateur manuel. Le débit du transducteur est amplifié et indiqué par un moniteur de pression standard. Le débit peut être communiqué à un display digital si on le désire, ou à un enregistreur graphique afin de surveiller la pression a un endroit donné pendant une période de temps donné.

\section{ZUSAMMENFASSUNG}

Viele Faktoren sind entscheidend für ihr Entstehen von Druckgschwären, der wichtigste jedoch ist aussergewöhnlich langanhaltender Druk.

Das Problem ist beim sitzenden Patienten am grössten, da das gleiche Gewicht auf eine sehr viel kleinere Fläche verteilt ist, als beim Liegenden.

Eine neue Apparatur der Druckmessung ist beschrieben. Der Apparat besteht aus zehn Sensoren, die an ein Verstärker/Aufzeichnungssystem über einen genormten Physiologiedruck-Überträger angeschlossen sind. Es folgt eine kurze Beschreibung der Methode, die durch einige bezeichnende Ergebnisse veranschaulicht ist.

Die Anlage ist um einen genormten Physiologiedruck-Überträger befestigt. Zehn mit Wasser gefüllte Drucksensoren sind durch Plastikröhrchen über einen manuellen Schalthebel mit dem Überträger verbunden, dessen Leistung verstärkt und von einem genormten Druckmonitor registriert wird. Falls erwüncht, kann die Leistung zu einem Digitalaufzeichner geführt werden, oder zu einem Diagrammrekorder, um den Druck an einer Stelle über einen gewissen Zeitraum aufzunehmen. Die mit diesem Apparat erzielten Ergebnisse werden beschrieben.

\section{REFERENCES}

ARnott, N. (1833). Elements of Physics or Natural Philosophy, Volume I. Langman, Rees, Orme, Crown and Green, London.

Bauman, J. H. \& BRAND, P. W. (I963). Measurement of pressure between foot and shoe. The Lancet, 629-632.

Brooks, B. \& Duncan, G. W. (1940). Effects of pressure on tissues. Archives of Surgery, 40, 696-709.

Chow, W. W., Juvinall, R. C. \& Cockrell, J. L. (1976). Effects and Characteristics of Cushion-covering Membrande, Bedsore Biomechanics. Macmillan Press, London.

Cochran, G. V. \& Slater, G. (1973). Experimental evaluation of wheelchair cushions: report of a pilot study. Bull. of Prosthetics Research, BPR, 10-19, 29-6I.

Cox, L. (I975). Prevention of decubitus ulcers in spinal paralysis, the wheelchair patients. A Clinical Nursing Research Project. 
Dawson, R. L. G. (I974). Treatment of pressure sores. Nursing Times, I IO8-I IIO.

DE LATEUR, B. J., BERNI, R., HongladAROM, T. \& Giaconi, R. (I976). Wheelchair cushions designed to prevent pressure sores: an evaluation. Archives of Physical Medicine and Rehabilitation, 57, I29-135.

DinsDale, S. M. (I973). Decubitus ulcers in swine: light and electron microscopy study of pathogenesis. Archives of Physical Medicine and Rehabilitation, 54, 5I-56.

DinsDale, S. M. (1974). Decubitus ulcers: role of pressure and function in causation. Archives of Physical Medicine and Rehabilitation, 55, I47-152.

Frisina, W. \& LeHNEIS, H. R. (I970). Pressure mapping: a preliminary report. F. Biomechanics, 3, 526 .

Grant, W. R. (1967). Weightlessness in the treatment of bed sores and burns. Proceedings of Royal Society of Medicine, 60, 7I I-7I 5.

Hassard, G. H. \& RICE, W. (I97I). Bucket seat for control of decubitus ulcers. Archives of Physical Medicine and Rehabilitation, 52, 48I-484.

Houle, R. J. (1969). Evaluation of seat devices designed to prevent ischaemic ulcers in paraplegic patients. Archives of Physical Medicine and Rehabilitation, 50, 587-594.

JACKSON, F. E., WOJCIK, V. F. \& WOJCIK, W. R. (I975). Rocking platform for paraplegic patients in wheelchairs. $\mathcal{f}$. Neurosurgery, 42, 358-359.

JonEs, R. F. \& BuRniston, G. G. (I97I). The water bed in a spinal injury unit. The Medical fournal of Australia, I2I5-I22I.

Jones, R. F., Hatzidoulis, C., Chestnutt, V. \& Stewart, L. (1975). The 'Coast' hydrostatic bed. Medical fournal of Australia, I, 333-335.

Koreska, J. \& AlBISSER, A. M. (I975). A new foam for support of the physically handicapped. Biomedical Engineering, 56-62.

Kosiak, M. (I 959). Etiology and pathology of ischemic ulcers. Archives of Physical Medicine and Rehabilitation, 40, 62-69.

Kosiak, M. (I969). Etiology of decubitus ulcers. Archives of Physical Medicine and Rehabilitation, 421, I9-29.

KosIAK, K. (I976). A mechanical resting surface: its effect on pressure distribution. Archives of Physical Medicine and Rehabilitation, 57, 48I-484.

Kosiak, M., Kubicek, W. G., Wilson, M., Danz, J. N. \& Kottke, F. J. (I958). Evaluation of pressure as a factor in the production of ischial ulcers. Archives of Physical Medicine and Rehabilitation, 39, 623-629.

LANDIS, E. M. (1930). Micro-injection studies of capillary blood pressure in human skin. Heart, 15, 209.

Lereim, P. \& BerCK-Hanssen, F. (I973). A method of recording pressure distribution under the sole of the foot. Bull. of Prosthetics Research, BPR, 10-r9.

Lindan, O. (I96I). Etiology of decubitus ulcers: an experimental study. Archives of Physical Medicine and Rehabilitation, 42, 774-783.

Lindan, O., GreENWAy, R. M. \& Piazza, J. M. (I965). Pressure distribution on the surface of the human body. Archives of Physical Medicine and Rehabilitation, 46, 378-385.

Lowthian, P. T. (I970). Bed sores-the missing links? Nursing Times, I454-I 458.

MA, D. M., CHU, D. S. \& DAvis, S. (I976). Pressure relief under the ischial tuberosities and sacrum using a cut and board. Archives of Physical Medicine and Rehabilitation, $57,352-354$.

McCubBIn, K. J. \& Simpson, D. C. (1977). A low pressure air bed. F. of Medical Engineering and Technology, 98-99.

Malament, I. B., DunN, M. E. \& Davis, R. (1975). Pressure sores: an operant conditioning approach to prevention. Archives of Physical Medicine and Rehabilitation, 56, I6I-165.

MolNAR, G. W. (1972). An inexpensive alternating support bed for the prevention of bed sores. 25th Annual Conference for Engineering in Medicine and Biology, 13.2.

Mooney, V., Einbund, M. J., Rogers, J. E. \& Stauffer, E. S. (I97I). Comparison of pressure distribution qualities in seat cushions. Bull. of Prosthetics Research, BPR, I0-I6, I29-I43.

Norton, D. (I962). Geriatric nursing problems. International Nursing Review, 9, 39.

OATES, G. D. (I975). Prevention of preoperative pressure sores during pelvic surgery. The Lancet, 202.

Paradis, R., Williams, M., Manthey, A., Nickerson, J., Roberts, C. \& Himmelwright, M. (I975). Floatation pad therapy for decubitus ulcers. Archives of Physical Medicine and Rehabilitation, 56, 40-43.

RAE, J. W. \& COCKRELL, J. L. (I97I). Interface pressure and stress distribution in prosthetic fitting. Bull. of Prosthetics Research, BPR, 10-16, 64-I I I. 
ReICHel, S. M. (1958). Shearing force as a factor in decubitus ulcers in paraplegics. F.A.M.A., $762-763$.

Reswick, J. B., Simoes, N. F. \& Rogers, J. (I972). High density floatation system for prevention and therapy of pressure sores-The M.U.D. Bed. 25th Annual Conference of Engineering in Medicine and Biology, r3.r.

SOuther, S. G., CARR, S. D. \& Vistnes, L. M. (I974). Wheelchair cushions to reduce pressure under bony prominences. Archives of Physical Medicine and Rehabilitation, $55,460-464 \mathrm{~m}$.

SPENCE, W. R. (1967). Gel support for prevention of decubitus ulcers. Archives of Physical Medicine and Rehabilitation, 48, 283-288.

StaRk, H. L. (I977). Directional variations in the extensibility of human skin. British fournal of Plastic Surgery, 30, I05-I I4.

TRUMBLE, H. C. (I930). The skin tolerance for pressure and pressure sores. The Medical Fournal of Australia, 724-726.

Weinstein, J. D. \& Davidson, B. A. (1965). A fluid support mattress and seat for the prevention and treatment of decubitus ulcers. The Lancet, 625-626.

Weinstein, J. D. \& Davidson, B. A. (I966). Fluid support in the prevention and treatment of decubitus ulcers. Amer. F. of Physical Medicine, 45, 283-290. 